more occasions has a 9 in 10 chance of being delivered of a severely affected infant. At the same time it should be noted that about one-third of severe cases will be missed, so that HPL levels cannot be relied on as the sole diagnostic criterion. Nevertheless, when the simplicity and low cost of this test is taken into account there can be little doubt that serial levels of HPL are a valuable adjunct to other methods of diagnosis in rhesus isoimmunization.

The assays were supported by grants from the Medical Research Council and the Board of Governors of St. Bartholomew's Hospital and were performed by Miss Linda Howard. We are grateful to the medical and nursing staff of University College Hospital and St. Bartholomew's Hospital for their co-operation in this study, and to Professor D. V. I. Fairweather for his encouragement and advice.

\section{References}

Fairweather, D. V. I., Billewicz, W., Loraine, J. A., and Bell, E. T. (1972). Fournal of Obstetrics and Gynaecology of the British Commonwealth, 79, 97.
Genazzani, A. R., Aubert, M. L., Casoli, M., Fioretti, P., and Felber, J. P. (1969). Lancet, 2, 1385

Genazzani, A. R., et al. (1971). Fournal of Obstetrics and Gynaecology of the British Commonwealth, 78, 577.

Haour, F., Cohen, M., and Bertrand, J. (1971). Revue Européenne d'Etudes Cliniques et Biologiques, 16, 124.

Josimovich, J. B., Kosor, B., and Mintz, D. H. (1969). Foetal Autonomy, ed. G. E. W. Wolstenholme and M. O'Connor. p. 117. London, Churchill.

Josimovich, J. B., Kosor, B., Boccella, L., Mintz, D. H., and Hutchinson, D. L. (1970). Obstetrics and Gynecology, 36, 244.

Letchworth, A. T., Boardman, R. J., Bristow, C., Landon, J., and Chard, T. (1971). Fournal of Obstetrics and Gynaecology of the British Commonwealth, 78, 542 .

Pridmore, B. R., Robertson, E. G., and Walker, W. (1972). British Medical fournal, 3, 136 .

Samaan, N. A., Bradbury, J. T., and Goplerud, C. P. (1969). American fournal of Obstetrics and Gynecology, 104, 781.

Singer, W., Desjardins, P., and Friesen, H. G. (1970). Obstetrics and Gynecology, 36, 222 .

Spellacy, W. N., Teoh, E. S., and Buhi, W. C. (1970). Obstetrics and Gynecology, 35, 685 .

Spellacy, W. N., Teoh, E. S., Buhi, W. C., Birk, S. A., and McReady, S. A. (1971). American fournal of Obstetrics and Gynaecology, 109, 588

Ursell, W., Brudenell, M., and Chard, T. (1973). British Medical fournal, 2, 80 .'

Varma, K., Driscoll, G. S., Emerson, K., and Selenkow, H. A. (1971). American fournal of Obstetrics and Gynecology, 38, 487.

\title{
Plasma Testosterone and Testosterone Binding Affinities in Men with Impotence, Oligospermia, Azoospermia, and Hypogonadism
}

tation but usually without noticeable clinical improvement. There appear to be few published data on plasma testosterone levels in impotent males, though there are reports that these men have a lower urinary testosterone excretion. Thus Ismail et al. (1970) compared 28 impotent men with 14 normal sexually active males and found the overall mean urinary testosterone excretion of the former to be significantly lower than that of the normal group $(P<0.001)$. Cooper et al. (1970) classified their impotent patients into predominantly psychogenic or predominantly constitutional groups and found the mean urinary testosterone of the latter group to be significantly lower $(P<0.005)$. Rosen and Weintraub (1971) reported on serum testosterone and luteinizing hormone concentration in idiopathic oligospermia and found a mean serum testosterone value of $560 \mathrm{ng} / 100 \mathrm{ml}$ for 17 idiopathic oligospermic or azoospermic men aged 18 to 36 . This was lower than the mean for normal men, $620 \mathrm{ng} / 100 \mathrm{ml}$, but the difference was not statistically significant $(P>0 \cdot 1)$. The luteinizing hormone concentration was similar in both groups.

We have investigated the plasma testosterone concentration in normal and impotent men and in men with oligospermia and azoospermia, as well as in a group of men with clinical evidence of hypogonadism. We have also evaluated testosterone binding affinities in most of the subjects.

\section{Subjects}

The 27 normal men were hospital personnel aged 20 to 63 (mean 37 years), sexually active, and normospermic. Details of the 27 men with impotence aged 21 to 62 (mean 43 years) are given in the table.

The 20 men with oligospermia (sperm counts persistently less than 20 million $/ \mathrm{ml}$ ) aged 22 to 44 (mean 30 years) and the 18 men with azoospermia aged 25 to 34 (mean 29 years) had normal external genitalia and secondary sex characteristics on clinical examination. They were attending the fertility or endocrine clinics at University College Hospital. The group 
Clinical Data on Impotent Men

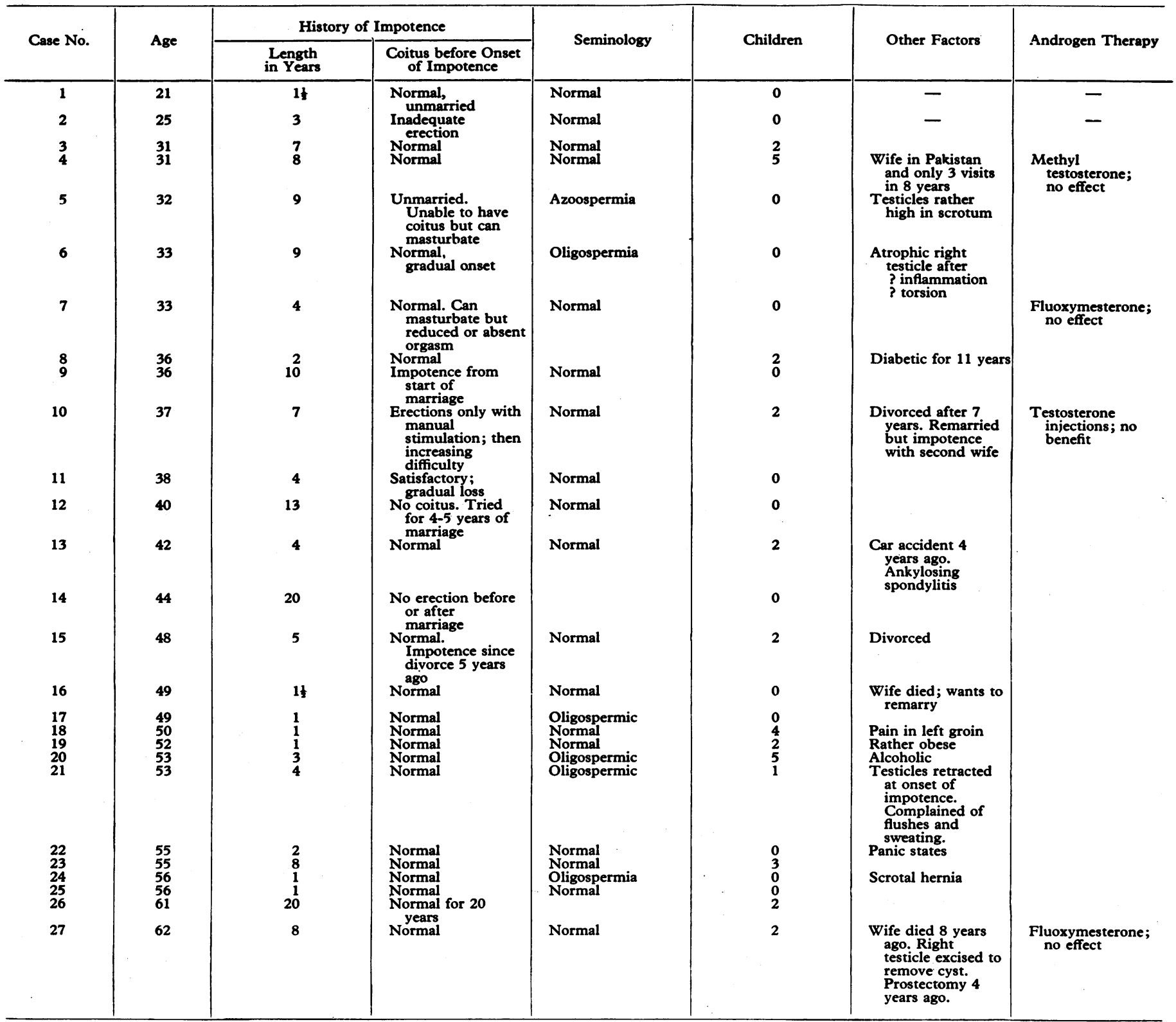

with clinical evidence of hypogonadism were aged 14 to 45 (mean 29 years), details of whom have been given previously (Lawrence and Swyer, 1973).

\section{Materials and Methods}

Blood was drawn into heparinized tubes between 09.30 and 12.00 and between 13.30 and 16.00 hours from both the patients and the normal controls. The significance of a circadian rhythm in testosterone levels with higher values expected in the morning and lower levels in the late afternoon was appreciated but it is believed that the scatter of times of venesection was similar for all the groups of men studied.

The plasma testosterone was extracted after separation on short columns ( 13 by $0.7 \mathrm{~cm}$ ) of Sephadex LH-20 and measured by competitive protein binding using ammonium sulphate precipitation of the bound testosterone. The method used was that of Lawrence and Swyer (1973) as modified from those of Murphy (1970) and Mayes and Nugent (1968).

Testosterone binding affinity was measured by the method of August et al. (1969). In this method testosterone affinity is expressed as $1 / \mathrm{S}$, the reciprocal of the quantity of plasma needed to bind $50 \%$ of $0.5 \mathrm{ng}$ of $1,2{ }^{3} \mathrm{H}$-testosterone (specific activity $40-45 \mathrm{Ci} / \mathrm{mmol}$ ). Florisil was used to remove the unbound testosterone.

\section{Results}

The plasma testosterone levels in the 27 normal males ranged from 408 to $1,022 \mathrm{ng} / 100 \mathrm{ml}$ (mean ( \pm S.D.) $629 \pm 160$ ). The range for the 27 impotent men was 352 to $1,14 \overline{7} \mathrm{ng} / 100 \mathrm{ml}$ (mean $650 \pm 205$ ). The 20 men with oligospermia had values of 368 to $1,060 \mathrm{ng} / 100 \mathrm{ml}$ (mean $644 \pm 178$ ), and the 18 men with azoospermia 365 to $766 \mathrm{ng} / 100 \mathrm{ml}$ (mean $563 \pm 125$ ). The range for the group of 21 men with hypogonadism was 30 to 378 $\mathrm{ng} / 100 \mathrm{ml}$ (mean $177 \pm 122$ ).

The individual results are plotted in fig. 1. Though the scatter was greater in the impotent group the difference between the mean values of this and the normal group was not significant $(P>0.7)$. Similarly, the mean value for the men with oligospermia was not significantly different from that of the normal group though the mean value for the azoospermic group was lower, but again the difference was not statistically significant $(P>0 \cdot 1)$. On the other hand, for the hypogonadal group the 


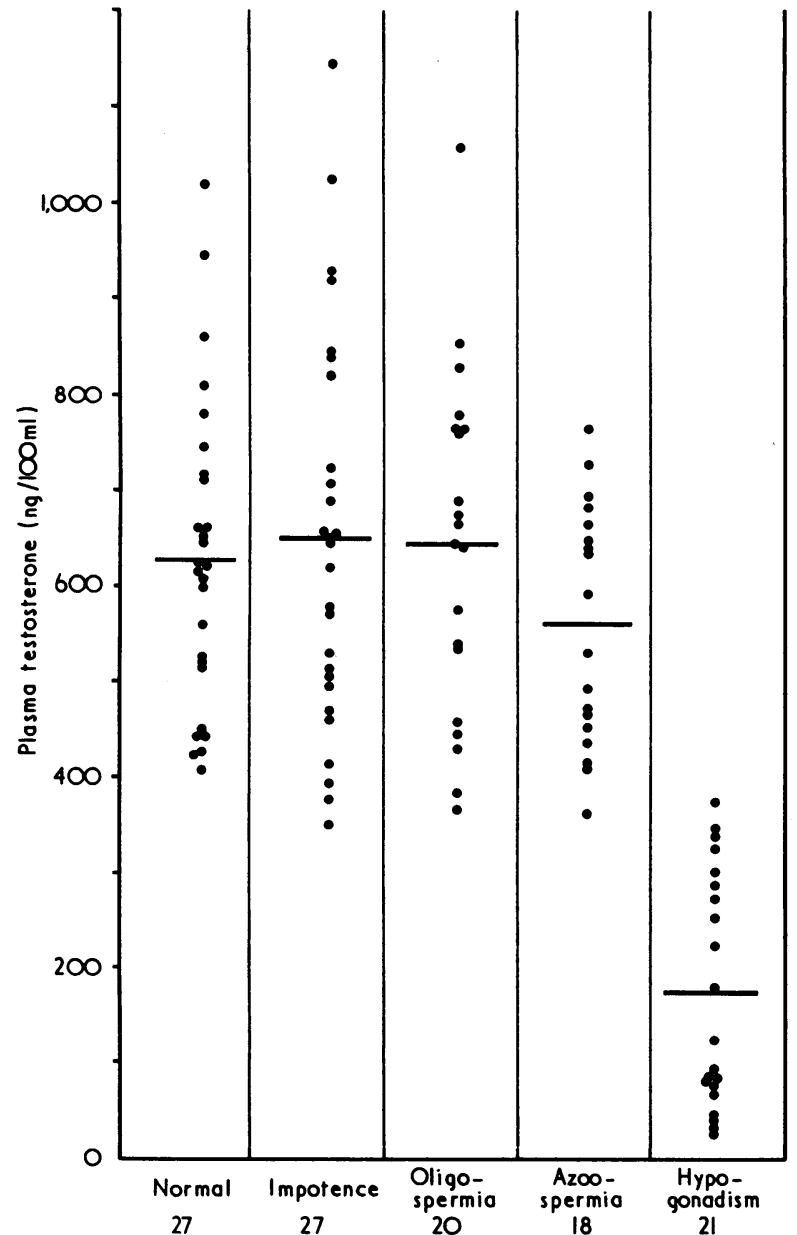

FIG. 1-Plasma testosterone values in normal men and those with either impotence, oligospermia, azoospermia, or hypogonadism.

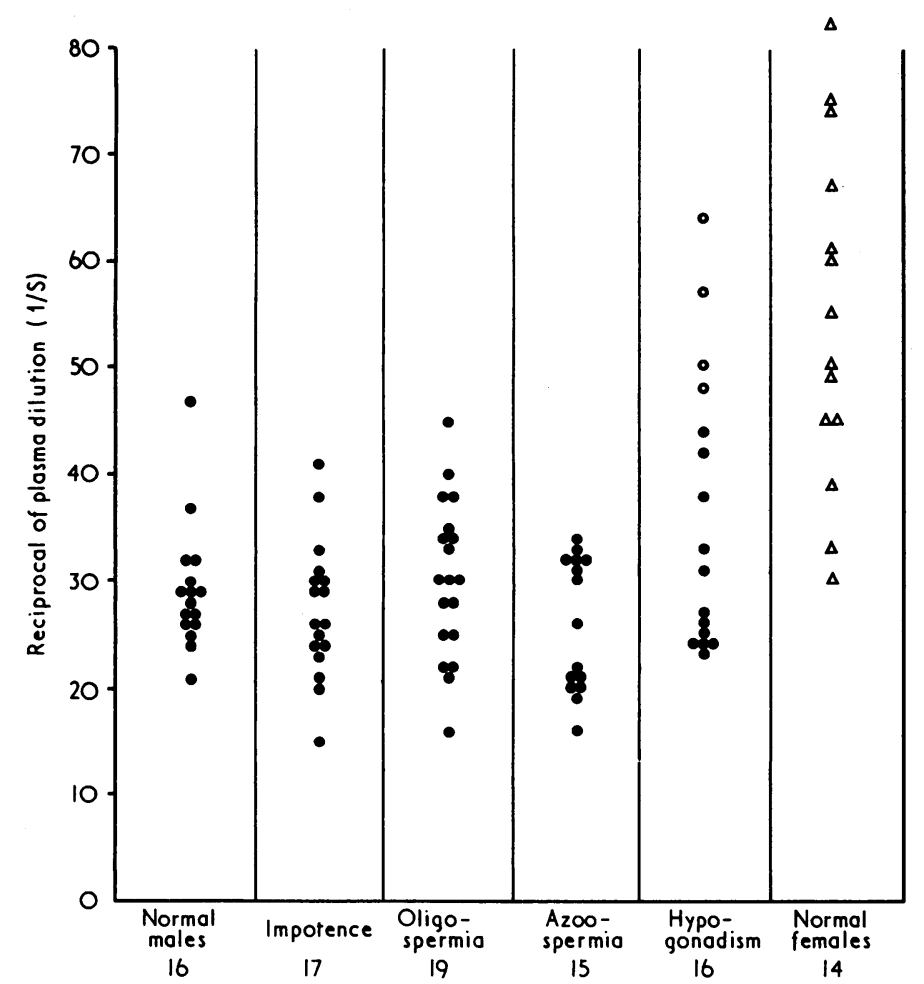

FIG. 2-Binding affinities for testosterone (expressed as $1 / \mathrm{S}$, reciprocal of quantity of plasma needed to bind $50 \%$ of ${ }^{3} \mathrm{H}$-testosterone tracer) in groups of normal, impotent, oligospermic, azoospermic, and hypogonadal subjects. $\mathrm{O}=$ Delayed puberty. mean plasma testosterone value was highly significantly lower than that of the normal group $(P<0.001)$.

The mean testosterone binding affinity of the normal men did not differ significantly from that of the oligospermic men $(P>0.6)$, the impotent men $(P>0.3)$, or the azoospermic men $(P>0 \cdot 1)$. The hypogonadal group had a higher mean binding affinity in comparison with that of the normal men but this was due to four of the 16 subjects aged 15 to 19 with delayed puberty whose values were similar to those of our normal female subjects. These have nearly double the binding capacity of adult males and the same has been found in prepubertal male children by August et al. (1969). The individual results are plotted in fig. 2 together with 14 values for normal female subjects.

\section{Conclusion}

The finding that there was no deficiency of plasma testosterone in a group of impotent but otherwise normal men helps to explain why androgen therapy is usually unsuccessful in the treatment of impotence. Three of the present cases had previously been treated with testosterone oenanthate by injection or fluoxymesterone by mouth and had not shown improvement. Intramuscular injections of testosterone-oenanthate $250 \mathrm{mg}$ can markedly raise plasma testosterone-for example, up to $2,000 \mathrm{ng} / 100 \mathrm{ml}$ testosterone seven days after injection-yet in spite of these high levels impotent males generally obtain little or no benefit-in striking contrast to hypogonadal males.

We have not attempted to explain the discrepancy between our findings of normal plasma testosterone and the low urinary testosterone reported by other workers. Ansari et al. (1973) reported reduced urinary testosterone excretion in impotent patients but, like us, they found normal plasma testosterone levels. They also reported a raised luteinizing hormone concentration and a reduced oestrogen excretion. One of our patients (case 27) aged 62 has been treated with oestrogen and showed some response. Teter (1972) claimed that mixed oestrogen and androgen therapy gives better results in selected cases of the so-called male climacteric with impotence than testosterone alone.

Our data on plasma testosterone in oligospermia and azoospermia confirm the findings of Rosen and Weintraub (1971). We also find that the testosterone binding affinities in these groups are normal.

It is noteworthy that the older but not the younger hypogonadal males have normal adult male testosterone binding affinities in spite of their low plasma testosterone levels. Why adult men, whether normal or hypogonadal, have lower testosterone binding affinities than women and prepubertal boys remains obscure.

Thanks are due to Mr. V. Asta for preparing the figures. The Wellcome Trust are thanked for a generous grant for the purchase of the Packard Tri-Carb model 3375 liquid scintillation spectrometer.

\section{References}

Ansari, M. A., Glover, T. D., Racey, P. A., and Rowe, P. H. (1974). Fournal of Endocrinology, In press.

August, G. P., Tkachuk, M., and Grumbach, M. M. (1969). Fournal of Clinical Endocrinology and Metabolism, 29, 891.

Cooper, A. J., Ismail, A. A. A., Smith, C. G., and Loraine, J. A. (1970). British Medical fournal, 3, 17.

Ismail, A. A. A., et al. (1970). In Reproductive Endocrinology, ed. W. J. Irvine, p. 138. Edinburgh, Livingstone.

Lawrence, D. M., and Swyer, G. I. (1973). Annals of Clinical Biochemistry, $10,115$.

Mayes, D., and Nugent, C. A. (1968). Fournal of Clinical Endocrinology and Metabolism, 28, 1169.

Murphy, B. E. P. (1970). In Steroid Assay by Protein Binding, ed. E. Diczfalusky, p. 37. Copenhagen, Bogtrykkeriet.

Rosen, S. W., and Weintraub, B. D. (1971). Fournal of Clinical Endocrinology and Metabolism, 32, 410.

Teter, J. (1972). British Medical fournal, 4, 114. 